\title{
GAMBARAN SEKTOR KETENAGAKERJAAN DAN KEMISKINAN DI PROVINSI BENGKULU
}

\section{${ }^{1}$ Muhammad Basorudin, ${ }^{2}$ Rizka Heryanti, ${ }^{3}$ Nadia Humairo, ${ }^{4}$ Anggoro Widyapuji Putro, dan ${ }^{5}$ Alfada Maghfiri Firdani}

\author{
1,2,3,4,5Badan Pusat Statistik
}

JI. Dr. Sutomo No.6-8, Jakarta

E-mail: m.basorudin@gmail.com

\begin{abstract}
Employment is the best way to get out of poverty. One effort to reduce poverty levels is utilization of the workforce at productive age. Uniquely, this condition doesn't work for Bengkulu Province. Poverty is still being serious problem and unfortunately labor force participation rate is high. This case made big question, what cause of disobedience for Bengkulu Province, so it's interesting to do analysis. The analysis used primary data from Susenas (National Sosioeconomic Survey) and used descriptive analysis method, which independent variable are locational (rural/urban), sex, last education, employment status, and employment opportunities. The result showed that employment opportunities indicates the existence of influence to poverty.
\end{abstract}

Keywords: Employment; poverty; Bengkulu; Susenas.

Abstrak

Ketenagakerjaan merupakan jalan keluar terbaik dari situasi kemiskinan. Salah satu upaya untuk menurunkan tingkat kemiskinan adalah melalui pemanfaatan angkatan kerja pada usia produktif untuk bekerja. Uniknya, kondisi ini tidak berlaku untuk Provinsi Bengkulu. Kemiskinan masih menjadi permasalahan serius bagi provinsi ini dan ternyata TPAK Bengkulu cukup tinggi. Hal ini tentunya menjadi sebuah pertanyaan besar penyebab ketidakberlakuan teori Rowntree untuk wilayah Bengkulu, sehingga menarik untuk dilakukan analisis. Analisis ini menggunakan data primer dari Susenas (Survei Sosial Ekonomi Nasional) dan metode analisis deskriptif dengan variabel independen adalah klasifikasi daerah, jenis kelamin, pendidikan tertinggi, status tenaga kerja, dan lapangan kerja serta ingin menduga pengaruh variabel penduga terhadap kemiskinan. Hasil penelitian menunjukkan bahwa lapangan kerja mengindikasikan adanya pengaruh terhadap kemiskinan.

Kata kunci : Ketenagakerjaan; Kemiskinan; Bengkulu; Susenas.

\section{PENDAHULUAN}

Kemiskinan adalah salah satu permasalahan serius yang dihadapi oleh negara di seluruh dunia, tidak terkecuali Indonesia. Kemiskinan timbul akibat dari keterbatasan seseorang untuk memenuhi kebutuhannya. Masalah kemiskinan di Provinsi Bengkulu menjadi masalah yang serius untuk dihadapi. Menurut data Badan Pusat Statistik (BPS) tahun 2015, persentase penduduk miskin di Bengkulu cukup tinggi, yaitu sebesar 17,88 persen dan menjadi provinsi dengan tingkat kemiskinan tertinggi kedua di Pulau Sumatera setelah Provinsi Aceh. Jika dilihat secara nasional, Bengkulu menempati peringkat keenam dengan tingkat kemiskinan tertinggi di Indonesia pada tahun yang sama. 
Kemiskinan dapat ditinjau dari berbagai sisi, salah satunya dari ketenagakerjaan. Pada dasarnya tujuan seseorang untuk bekerja adalah untuk memperoleh penghasilan sehingga dapat digunakan untuk memenuhi kebutuhan hidup. Oleh karena itu, pemerintah terus berupaya untuk meningkatkan angka tingkat partisipasi angkatan kerja (TPAK), sebab ketenagakerjaan dapat menjadi sumber masalah kemiskinan Jika suatu wilayah memiliki jumlah penduduk yang berstatus tidak bekerja lebih banyak, maka akan berimplikasi pada peningkatan jumlah penduduk miskin. Jika ditinjau dari sisi ketenagakerjaan, Bengkulu merupakan provinsi dengan TPAK yang cukup tinggi, yaitu sebesar 73,59 persen pada tahun 2015 dan menjadikannya provinsi dengan TPAK tertinggi keempat di Indonesia.

Uniknya, TPAK yang cukup tinggi tersebut justru diikuti oleh tingginya persentase kemiskinan. Hal ini tidak sejalan dengan teori yang ada karena menurut Rowntree (1918), ketenagakerjaan dipercaya menjadi jalan keluar terbaik dari situasi kemiskinan tersebut. Salah satu upaya untuk menurunkan tingkat kemiskinan adalah melalui pemanfaatan angkatan kerja pada usia produktif (15-64 tahun) untuk bekerja. Menurut Fahar (2015) dalam penelitiannya mengenai keterkaitan kemiskinan dan tenaga kerja, kemiskinan dapat diukur melalui klasifikasi daerah tenaga kerja, jenis kelamin, tingkat pendidikan, status tenaga kerja, upah/pendapatan tenaga kerja, serta lapangan pekerjaan. Berdasarkan fenomena unik yang terjadi di Bengkulu, permasalahan yang menarik untuk dikaji dalam penelitian ini adalah keterkaitan antara ketenagakerjaan dan kemiskinan pada tahun 2015.

Provinsi Bengkulu memiliki tingkat partisipasi angkatan kerja yang cukup tinggi. Hal ini dapat ditunjukkan dari grafik di bawah ini

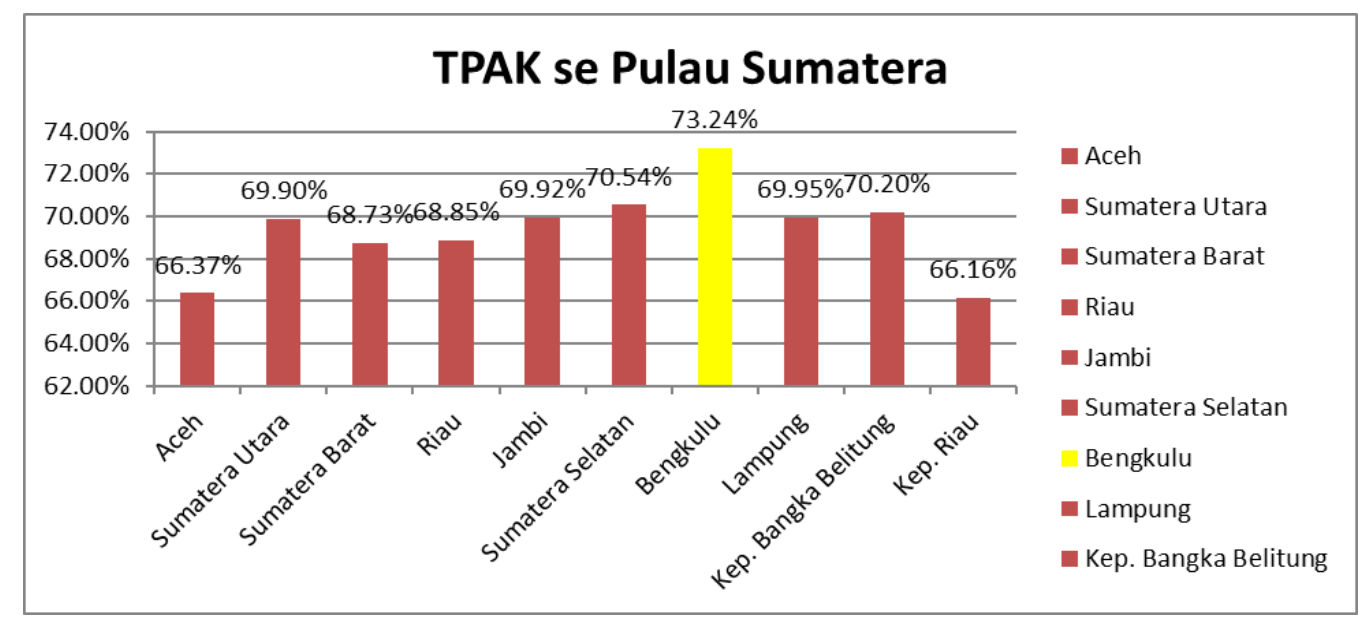

Sumber: BPS

Gambar 1. TPAK seluruh provinsi di Pulau Sumatera

Berdasarkan grafik tersebut, tingkat partisipasi angkatan kerja di Provinsi Bengkulu pada tahun 2015 adalah 73,24\% dan posisinya menempati peringkat teratas di Pulau Sumatera sedangkan untuk skala nasional, Provinsi Bengkulu menempati peringkat ke 4. Hal 
ini mengindikasikan bahwa penduduk usia kerja di Provinsi Bengkulu banyak yang mempunyai pekerjaan sehingga mampu untuk memenuhi kebutuhan hidup mereka

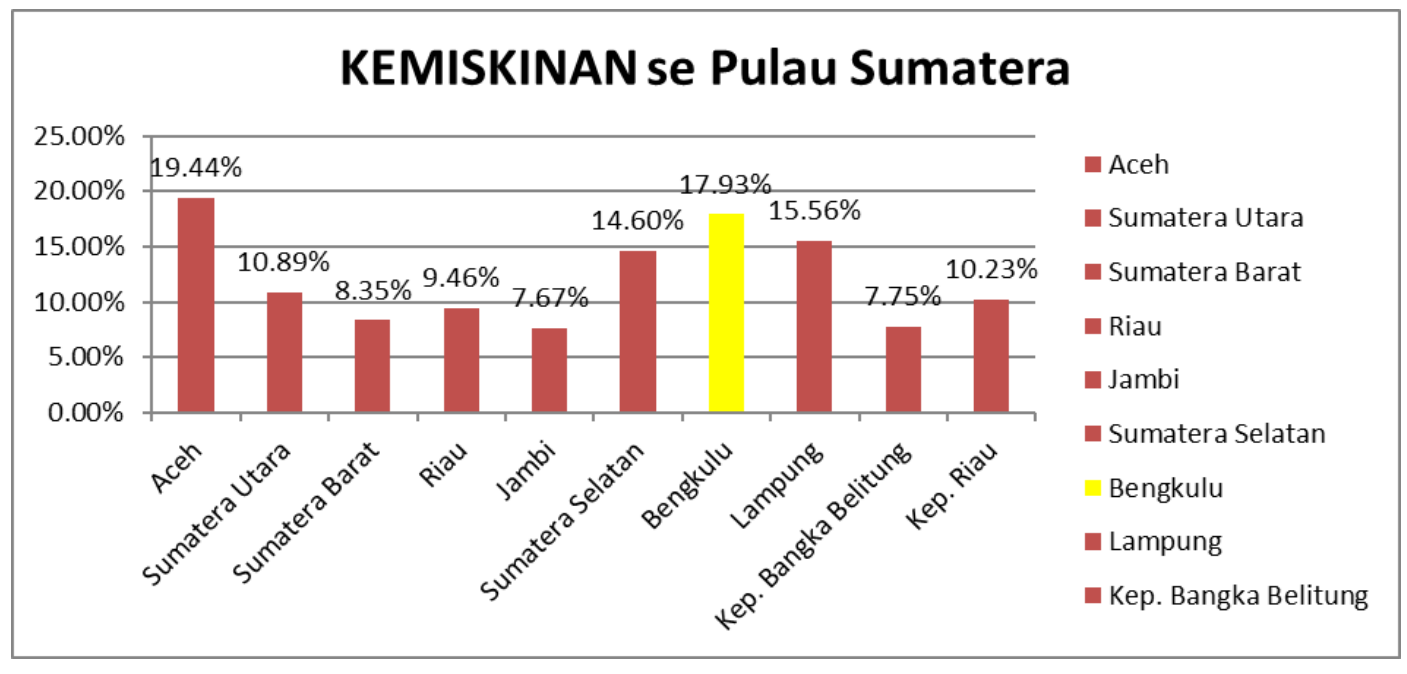

Sumber: BPS

Gambar 2. Tingkat Kemiskinan Provinsi di Pulau Sumatera

Pada grafik diatas, persentase kemiskinan di Provinsi Bengkulu adalah 17,88\%, sehingga Provinsi Bengkulu berada di peringkat ke 2 di Pulau Sumatera sedangkan untuk skala nasional, Provinsi Bengkulu menempati peringkat ke 6. Secara teori, tingkat partisipasi angkatan kerja yang tinggi seharusnya dapat menekan jumlah penduduk miskin. Hal ini tentunya menjadi sebuah pertanyaan tersendiri sebab Provinsi Bengkulu yang memiliki angka TPAK yang cukup tinggi akan tetapi diikuti dengan persentase penduduk miskin di Provinsi Bengkulu yang tinggi pula. Oleh karena itu, tujuan yang ingin dicapai dalam penelitian ini adalah untuk menganalisis gambaran keterkaitan antara kemiskinan dan ketenagakerjaan di Provinsi.

\section{LANDASAN TEORI}

\section{Kemiskinan}

Pemerintah melalui Bappenas (2004) mendefinisikan kemiskinan adalah kondisi dimana seseorang atau sekelompok orang tidak mampu memenuhi hak-hak dasarnya untuk mempertahankan dan mengembangkan kehidupan yang bermartabat.

Hak-hak dasar antara lain (a) terpenuhinya kebutuhan pangan, (b) kesehatan, pendidikan, pekerjaan, perumahan, air bersih, pertanahan, sumberdaya alam dan lingkungan hidup, (c) rasa aman dari perlakuan atau ancaman tindak kekerasan, (d) hak untuk berpartisipasi dalam kehidupan sosial-politik.

Berdasarkan definisi yang ada kemiskinan merupakan masalah yang multidimensi yang mencakup banyak aspek dari kehidupan manusia sebagai akibat berbagai keterbatasan kemampuan manusia termasuk dalam hal pekerjaan. 
Menurut Fahar (2015) kemiskinan muncul karena adanya gap antara ketersediaan sumber daya utama (essential resources) dengan kemampuan individu atau rumahtangga untuk memenuhi kebutuhan dasar.

Salah satu permasalahan pokok yang menjadi akar permasahan kemiskinan adalah rendahnya pendapatan penduduk miskin baik karena tidak adanya pekerjaan (menganggur) ataupun memiliki pekerjaan tetapi upah/pendapatan yang diperoleh rendah. Dengan demikian, terdapat pentingnya menganalisis kemiskinan yang ditinjau dari ketenagakerjaan.

\section{Ketenagakerjaan}

Menurut BPS, seseorang disebut bekerja bila melakukan kegiatan ekonomi memproduksi barang atau jasa dengan maksud memperoleh atau membantu memperoleh pendapatan atau keuntungan, paling sedikit 1 jam (tidak terputus) dalam seminggu yang lalu.

Kegiatan tersebut termasuk pula kegiatan pekerja tak dibayar yang membantu dalam suatu usaha/ kegiatan ekonomi. Penduduk yang termasuk dalam usia kerja yaitu berumur 15 tahun atau lebih, sehingga penduduk yang termasuk angkatan kerja adalah penduduk usia kerja (15 dan lebih) yang bekerja, atau punya pekerjaan namun sementara tidak bekerja dan pengangguran.

Pada pendekatan teori ketenagakerjaan yang digunakan dalam sakernas, terdapat beberapa konsep umum yang digunakan salah satunya konsep dan definisi mengenai angkatan kerja. Angkatan kerja terdiri dari penduduk yang bekerja, atau punya pekerjaan namun sementara tidak bekerja, dan pengangguran.

Dalam menganalisis ketenagakerjaan di Provinsi Bengkulu maka tenaga kerja dapat digolongkan menurut klasifikasi daerah, jenis kelamin, pendidikan tertinggi yang ditamatkan, status tenaga kerja, dan lapangan pekerjaan utama menurut tiga sektor.

\section{Klasifikasi Daerah}

Dalam peraturan kepala Badan Pusat Statistik Nomor 37 Tahun 2010 tentang klasifikasi perkotaan dan perdesaan di Indonesia, kriteria wilayah perkotaan adalah persyaratan tertentu dalam hal kepadatan penduduk, persentase rumah tangga pertanian, dan keberadaan/akses pada fasilitas perkotaan, yang dimiliki suatu desa/kelurahan untuk menentukan status perkotaan suatu desa/kelurahan.

Dalam hal tersebut, perkotaan adalah status suatu wilayah administrasi setingkat desa/kelurahan yang memenuhi kriteria klasifikasi wilayah perkotaan yaitu apabila dari kepadatan penduduk, persentase rumah tangga pertanian, dan keberadaan/akses pada fasilitas perkotaan yang dimiliki mempunyai total nilai/skor 10 (sepuluh) atau lebih.

Sedangkan perdesaan adalah status suatu wilayah administrasi setingkat desa/kelurahan yang belum memenuhi kriteria klasifikasi wilayah perkotaan yaitu apabila dari kepadatan penduduk, persentase rumah tangga pertanian, dan keberadaan/akses pada fasilitas perkotaan yang dimiliki mempunyai total nilai/skor di bawah 10 (sepuluh). 


\section{Jenis Kelamin}

Menurut BPS istilah gender digunakan untuk menjelaskan perbedaan peran perempuan dan laki-laki yang bersifat bawaan sebagai ciptaan Tuhan. Gender adalah pembedaan peran, kedudukan, tanggung jawab, dan pembagian kerja antara laki-laki dan perempuan yang ditetapkan oleh masyarakat berdasarkan sifat perempuan dan laki-laki yang dianggap pantas menurut norma, adat istiadat, kepercayaan atau kebiasaan masyarakat.

Gender tidak sama dengan kodrat. Kodrat adalah sesuatu yang ditetapkan oleh Tuhan YME, sehingga manusia tidak mampu untuk merubah atau menolak. Sementara itu, kodrat bersifat universal, misalnya melahirkan, menstruasi dan menyusui adalah kodrat bagi perempuan, sementara mempunyai sperma adalah kodrat bagi laki-laki.

\section{Pendidikan Tertinggi yang ditamatkan}

Pendidikan merupakan investasi yang sangat berguna dalam pembangunan ekonomi suatu wilayah (Fahar, 2015). Pendidikan merupakan usaha sadar dan terencana untuk mewujudkan suasana belajar dan proses pembelajaran agar perserta didik secara aktif mengembangkan potensi dirinya untuk memiliki kekuatan spiritual keagamaan, pengendalian diri, kepribadian, kecerdasan, akhlak mulia, serta keterampilan yang diperlukan dirinya, masyarakat, bangsa dan negara (BPS, 2009).

Menurut BPS, yang dimaksud dengan 'tamat' adalah selesai mengikuti pelajaran pada kelas tertinggi suatu sekolah sampai akhir dengan mendapatkan tanda tamat/ijazah. Seseorang yang belum mengikuti pelajaran pada kelas tertinggi, tetapi ia mengikuti ujian dan lulus, dianggap "tamat". Dalam SUPAS 2005, pendidikan yang ditamatkan dibagi menjadi 9 golongan yaitu:
a) Tidak punya;
b) Sekolah Dasar (SD)/MI/Sederajat;
c) Sekolah Lanjutan Tingkat Pertama (SLTP)/MTs/Sederajat/Kejuruan;
d) Sekolah Menengah Umum (SMU)/MA/Sederajat;
e) Sekolah Menengah Kejuruan;
f) Diploma I/II 7. Diploma III/Sarjana Muda;
g) Diploma IV/S1;
h) S2 dan S3

\section{Status Tenaga Kerja}

Berdasarkan jumlah jam kerja, BPS membagi tenaga kerja atas 3 macam yaitu: 1) Tenaga kerja penuh (full employed) adalah tenaga kerja yang mempunyai jumlah jam kerja lebih dari 35 jam dalam seminggu dengan hasil kerja tertentu sesuai dengan uraian tugas; 2 ) Tenaga kerja tidak penuh (under employed) adalah tenaga kerja yang mempunyai jumlah jam kerja kurang dari 35 jam dalam seminggu; 3) Tenaga kerja yang belum bekerja atau 
sementara tidak bekerja (unemployed) adalah tenaga kerja dengan jam kerja 0 lebih dari 1 jam per minggu.

\section{Lapangan Pekerjaan Menurut Tiga Sektor}

Menurut BPS, lapangan pekerjaan adalah bidang kegiatan dari pekerjaan/usaha/perusahaan/ kantor tempat seseorang bekerja atau pernah bekerja meliputi:

1) Sektor primer yang terdiri atas:Sektor pertanian dan Sektor pertambangan dan penggalian;

2) Sektor sekunder yang terdiri atas: Sektor ectorc pengolahan, ector listrik gas dan air, dan ector bangunan;

3) Sektor tersier yang terdiri atas: Sektor perdagangan, hotel dan restoran, ector pengangkutan dan komunikasi, ector keuangan, persewaan dan jasa perusahaan,dan sektor jasa-jasa

\section{Pengukuran}

\section{a. Pengukuran Kemiskinan}

Untuk mengukur kemiskinan, BPS menggunakan konsep kemampuan memenuhi kebutuhan dasar (basic needs approach). Dengan pendekatan ini, kemiskinan dipandang sebagai ketidakmampuan dari sisi ekonomi untuk memenuhi kebutuhan dasar makanan dan bukan makanan yang diukur dari sisi pengeluaran.

Menurut pendekatan ini, penduduk miskin adalah penduduk yangmemiliki rata-rata pengeluaran per kapita per bulan di bawah gariskemiskinan (GK).Garis Kemiskinan (GK) merupakan penjumlahan dari Garis Kemiskinan Makanan (GKM) dan Garis Kemiskinan NonMakanan (GKNM) sebagai berikut:

$$
\mathrm{GK}=\mathrm{GKM}+\mathrm{GKNM}
$$

Penghitungan Garis Kemiskinan dilakukan secara terpisah untuk setiap provinsi, daerah perkotaan dan perdesaan.

Garis Kemiskinan Makanan (GKM) adalah jumlah nilaipengeluaran kebutuhan minimum makanan yang disetarakan dengan 2100 kilokalori per kapita perhari. Paket komoditi kebutuhan dasar makanan diwakili oleh 52 jenis komoditi (padi-padian, umbi-umbian, ikan, daging, telur dan susu, sayuran, kacang-kacangan, buah-buahan, minyak dan lemak, dll).

Sedangkan Garis Kemiskinan Non-Makanan (GKNM) adalah kebutuhan minimum untuk perumahan, sandang, pendidikan, dan kesehatan. Paket komoditi kebutuhan dasar nonmakanan diwakili oleh 51 jenis komoditi (kelompok pengeluaran) di perkotaan dan 47 jenis komoditi (kelompok pengeluaran) di perdesaan.

Dengan demikian, penduduk yang memiliki rata-rata pengeluaran per kapita per bulan dibawah Garis Kemiskinan dikategorikan sebagai penduduk miskin (PM). Persentase penduduk miskin di suatu provinsi dihitung dengan: 


$$
\% \mathrm{PMp}=\frac{\mathrm{PMp}}{\mathrm{Pp}}
$$

dimana :

$\% \mathrm{PMp}=\%$ Penduduk miskin di provinsi $\mathrm{p}$.

PMp = Jumlah penduduk miskin di provinsi $p$.

$\mathrm{Pp}=$ Jumlah penduduk di provinsi $\mathrm{p}$.

\section{Penelitian Terdahulu}

Menurut Rowntree (1918) bahwa ketenagakerjaan dipercaya menjadi jalan keluar terbaik dari situasi kemiskinan tersebut salah satunya melalui pemanfaatan angkatan kerja usia produktif untuk bekerja. Dalam memahami keterkaitan antara masalah kemiskinan dan ketenagakerjaan, salah satu kerangka analisis yang tepat dikemukakan oleh Osmani (2002) bahwa penduduk miskin dapat dikelompokkan dalam dua kelompok yaitu penduduk miskin yang berada dalam angkatan kerja dan penduduk miskin yang berada di luar angkatan kerja.

Hal ini didukung oleh penelitian Fahar (2015) bahwa penduduk miskin yang berada di luar angkatan kerja biasanya memiliki ketergantungan secara ekonomi terhadap penduduk yang berada dalam angkatan kerja. Sedangkan penduduk miskin yang berada dalam angkatan kerja terbagi dua yaitu penduduk miskin yang bekerja dan penduduk miskin yang tidak bekerja. Pada penelitian Fahar (2015) menyatakan bahwa penduduk miskin yang tidak bekerja, sangat jelas bahwa kemiskinannya disebabkan ketiadaan pekerjaan sehingga tidak dapat memenuhi kebutuhan hidupnya yang utama dan di negara berkembang seperti Indonesia yang tidak memiliki jaminan asuransi bagi penganggur, jumlah kelompok ini tidak begitu besar. Sebaliknya yang paling menarik adalah penduduk miskin yang bekerja di mana pekerjaan yang dimilikinya tidak mampu memberikan penghasilan yang memadai untuk mencukupi kebutuhan hidupnya secara layak. Kelompok terakhir ini disinyalir memiliki proporsi terbesar dari seluruh penduduk miskin yang ada.

Penelitian ini mencakup seluruh pekerja yang terpilih sebagai sampel Survei Sosial Ekonomi Nasional (SUSENAS) di Provinsi Bengkulu tahun 2015. Total sampel yang tercakup adalah 3529 sampel.

\section{Metode Pengumpulan Data}

Seluruh data dalam penelitian ini bersumber dari data sekunder, yaitu raw data SUSENAS dan publikasi BPS tahun 2015. Berikut daftar data yang dikumpulkan:

1. Klasifikasi Daerah

2. Jenis Kelamin

3. Pendidikan Tertinggi yang ditamatkan

4. Status Tenaga Kerja

5. Lapangan Pekerjaan menurut tiga sektor

6. Garis Kemiskinan 


\section{Metode Analisis}

Metode analisis yang digunakan adalah analisis deskriptif dan inferensia. Deskriptif digunakan untuk menggambarkan pola masing-masing variabel, baik bebas maupun terikat.Selain itu, analisis inferensia juga digunakan untuk menjawab rumusan masalah melalui pengujian statistik.

\section{Analisis Deskriptif}

Statistik deskriptif memberikan gambaran mengenai suatu variabel yang dilohat dari rata-rata, standar deviasi, nilai maksimum dan nilai minimum (Ghozali, 2006). Analsis deskriptif menggunakan tabel dan grafik masing-masing variabel, baik bebas maupun terikat dengan tujuan untuk menggambarkan pola data tersebut.

\section{HASIL DAN PEMBAHASAN}

\section{Gambaran Karakteristik Tenaga Kerja dan Kemiskinan}

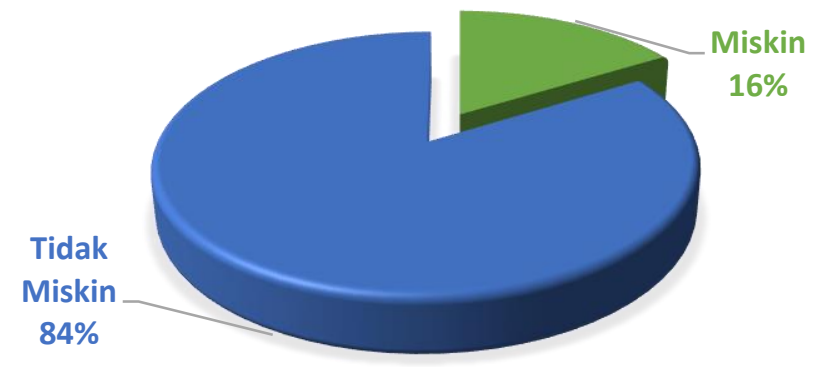

Gambar 3. Persentase tenaga kerja menurut status kemiskinan di Provinsi Bengkulu tahun 2015

Berdasarkan hasil pencacahan melalui SUSENAS 2015, sebanyak 3529 individu merupakan tenaga kerja. 16,3 persen tenaga kerja tergolong miskin dan sisanya dikategorikan tidak miskin, sehingga dapat diartikan bahwa hampir semua tenaga kerja di Bengkulu sudah memiliki penghasilan yang mampu memenuhi kebutuhan hidupnnya. Selanjutnya, akan dieksplorasi tenaga kerja dan keterkaitannya dengan kemiskinan melalui grafik.

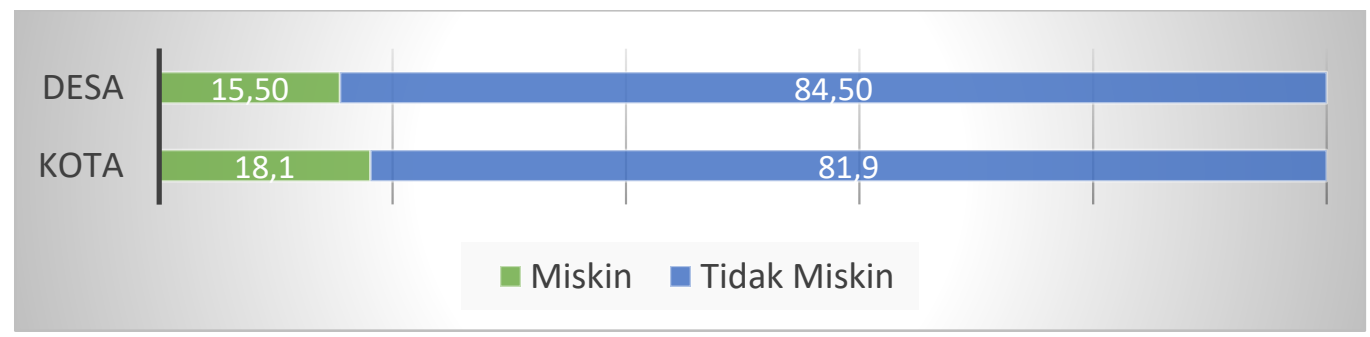

Gambar 4. Persentase tenaga kerja menurut desa/kota dan status kemiskinan di Provinsi Bengkulu tahun 2015

Berdasarkan gambar 4, persentase tenaga kerja yang tergolong miskin dan tidak miskin pada kategori wilayah dikatakan tidak berbeda jauh. Pada daerah kota, sebesar 18,1 persen 
tenaga kerja digolongkan miskin dan lebih besar dibandingkan dengan daerah desa. Daerah kota yang dianggap menjanjikan bagi tenaga kerja untuk memperoleh pekerjaan, namun faktanya belum mampu menyerap secara optimal. Hal demikian dapat terjadi karena penawaran tenaga kerja di kota melebihi permintaan tenaga kerja yang dibutuhkan. Dalam teori permintaan ekonomi, kelebihan penawaran tenaga kerja dibanding permintaan akan berdampak kepada upah yang diterima tidak besar atau terkadang dibawah upah minimum regional.

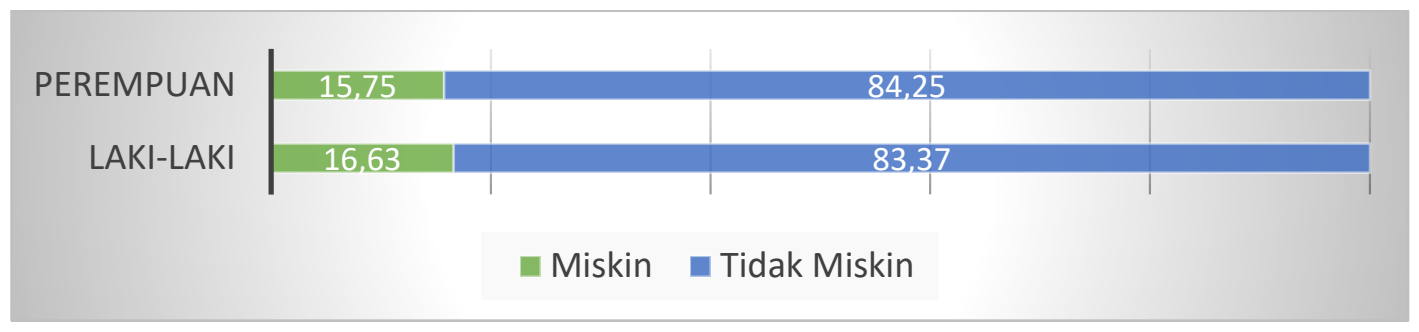

Gambar 5. Persentase tenaga kerja menurut jenis kelamin dan status kemiskinan di Provinsi Bengkulu tahun 2015

Meningkatkan partisipasi angkatan kerja untuk memasuki dunia kerja merupakan hal penting bagi setiap negara. Tiap tenaga kerja diharapkan dapat memenuhi kebutuhannya diawali dari diri sendiri, tanpa memandang jenis kelamin sehingga tidak ada ketergantungan kepada pihak lain. Jika diperhatikan pada gambar 5, persentase tenaga kerja yang miskin dan tidak miskin menurut jenis kelamin menunjukkan proporsi yang hampir sama.

Sekitar $84 \%$ tenaga kerja memiliki penghasilan yang mampu memenuhi kebutuhannya. Artinya dapat dikatakan hampir tidak ada perbedaan status kemiskinan baik tenaga kerja laki-laki maupun perempuan. Proporsi nilai yang tidak jauh ini mengindikasikan bahwa sudah cukup besar partisipasi perempuan dalam dunia kerja, meskipun masih terdapat kondisi mereka yang masih tergolong miskin.

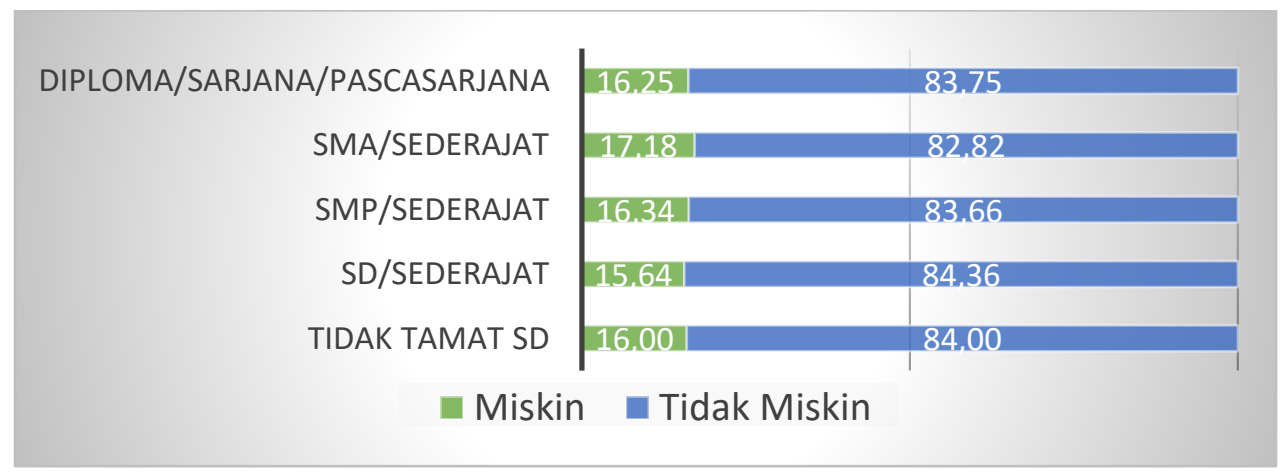

Gambar 6. Persentase tenaga kerja menurut pendidikan dan status Kemiskinan di Provinsi Bengkulu tahun 2015

Berdasarkan gambar 6, tenaga kerja yang miskin dengan pendidikan terakhir SMA/ Sederajat lebih tinggi dibandingkan tingkat pendidikan lainnya, yaitu sebesar $17,18 \%$. Sedangkan persentase pendidikan dengan miskin terendah yaitu tingkat pendidikan kurang 
atau sama dengan SD/Sederajat. Proporsi tiap tingkatan pendidikan baik kategori miskin dan tidak miskin dapat dikatakan hampir sama.

Persentase yang hampir sama pada tenaga kerja yang miskin di empat tingkat pendidikan mengindikasikan bahwa pendidikan tenaga kerja tidak mempengaruhi mereka untuk menjadi miskin. Secara teori, pendidikan merupakan investasi sumber daya manusia untuk mencegah terjadinya kemiskinan. Namun, dalam beberapa kejadian pendidikan belum mampu menjadikan seseorang yang berpendidikan tinggi secara pasti menjadi sukses secara finansial.

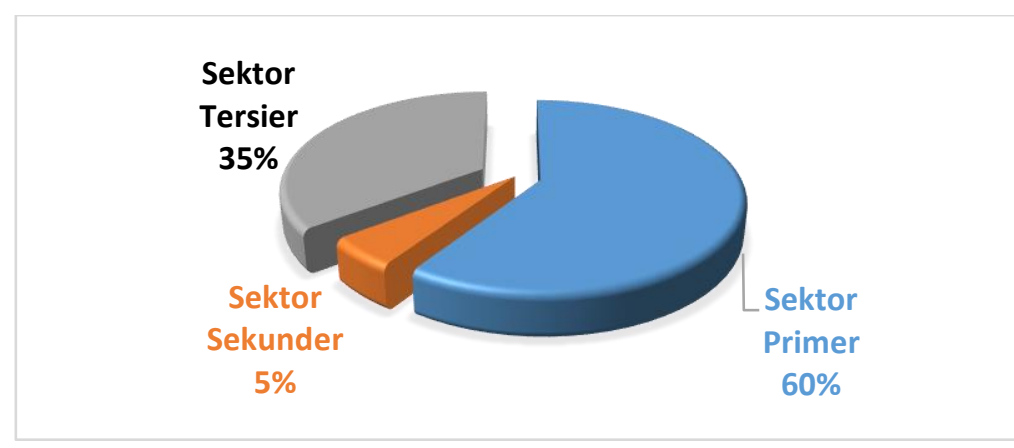

Gambar 7. Persentase tenaga kerja menurut sektor usaha di Provinsi Bengkulu tahun 2015

Berdasarkan gambar 7, tenaga kerja di Bengkulu terkonsentrasi pada sektor primer sebesar $60 \%$ dan diikuti sektor sekunder sebesar 35\%. Sektor Primer masih mempunyai proporsi yang besar dalam penyerapan tenaga kerja khususnya sektor pertanian, kehutanan dan perikanan.

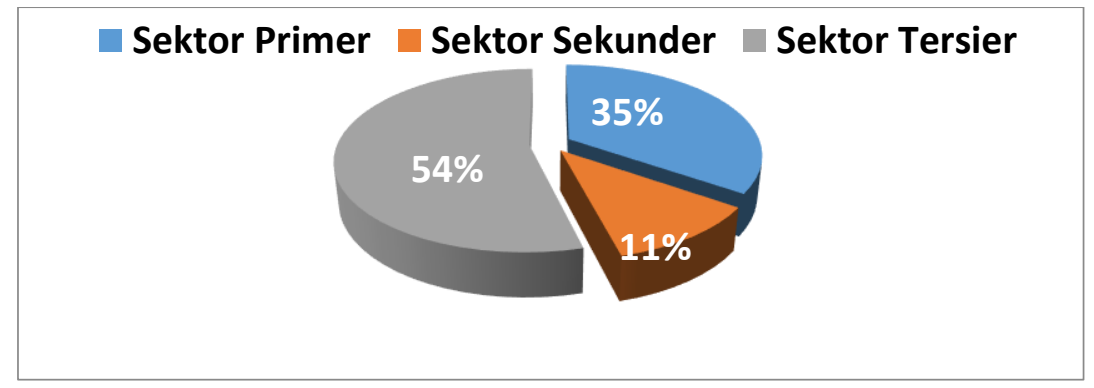

Gambar 8.Distribusi persentase produk domestik regional bruto Provinsi Bengkulu atas dasar harga berlaku menurut sektor usaha 2015

Dapat dilihat dari grafik 8 , sektor primer hanya menyumbang sebesar $34,63 \%$. Nilai tersebut jauh lebih kecil dibanding sumbangan dari sektor tersier sebesar $54,08 \%$. Melihat kontribusi PDRB tersebut, terjadi kejanggalan pada penyerapan tenaga kerja terhadap kontribusi dari PDRB pada sektor primer dan tersier. Dengan penyerapan tenaga kerja sebesar $60 \%$ sektor primer hanya menyumbang sebesar $34,63 \%$ PDRB. Sedangkan sektor tersier yang hanya menyerap $35 \%$ tenaga kerja dapat menyumbang $54,08 \%$ PDRB di 
Bengkulu. Eksplorasi mengenai tenaga kerja pada tiap sektor dapat ditelaah lebih lanjut dengan melihat karakteristik tiap sektor, seperti jumlah jam kerja dan pendidikan tenaga kerja.

Penetapan sistem jam kerja menjadi pertimbangan dalam menentukan pemberian upah kepada pekerja. Beberapa jenis pekerjaan yang menerapkan sistem ini memberikan upah lembur kepada pekerjanya jika pekerja melebihi waktu kerja tersebut dan menjadi hak setiap pekerja. Cut off waktu kerja ini juga mencerminkan bahwa tenaga kerja bekerja di lingkungan yang terstruktur, sehingga adanya keterkaitan yang kuat antara tenaga kerja terhadap pekerjaannya.

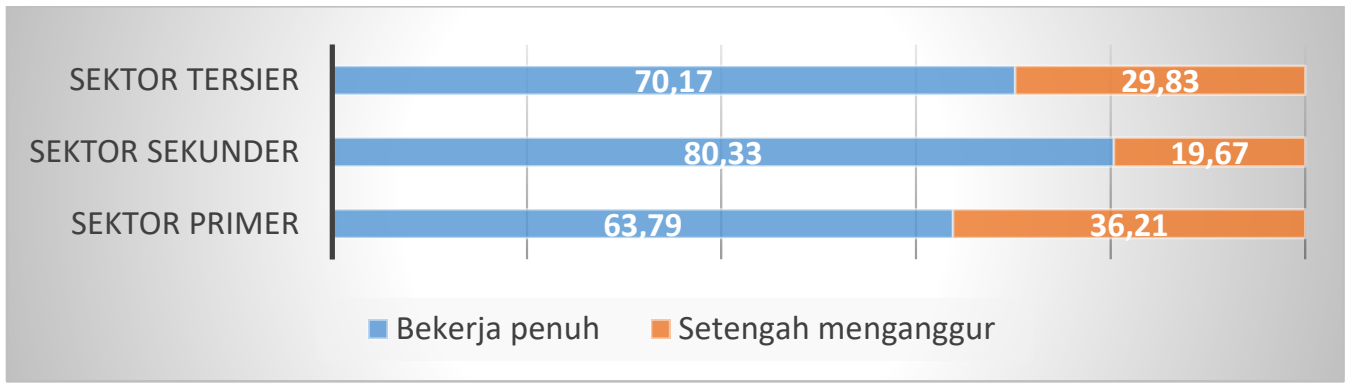

Gambar 9. Persentase tenaga kerja menurut sektor usaha dan status tenaga kerja Provinsi Bengkulu tahun 2015

Berdasarkan grafik 9 , hampir $80 \%$ tenaga kerja Bengkulu pada sektor sekunder berada dalam status bekerja penuh serta sektor tersier dan primer masing-masing yaitu $70,17 \%$ dan $63,79 \%$. Sektor yang paling produktif adalah sekunder, tenaga kerja di sektor ini terlalu kecil dibanding dua sektor lainnya. Sehingga wajar bila sektor sekunder hanya menyumbang $11 \%$ dari PDRB di Bengkulu. Fenomena lain yang tergambar mengatakan bahwa sektor tersier lebih produktif dibanding sektor primer. Hal ini merupakan salah satu penyebab tingginya kontribusi PDRB dari sektor tersier.

Meninjau tenaga kerja dari sisi yang berbeda, kecenderungan tenaga kerja terhadap suatu sektor bergantung pada pendidikan yang ditamatkan. Tenaga kerja Provinsi Bengkulu memiliki kecenderungan ketika tingkat pendidikannya meningkat atau semakin tinggi, maka konsentrasi bekerja pada sektor primer semakin berkurang.

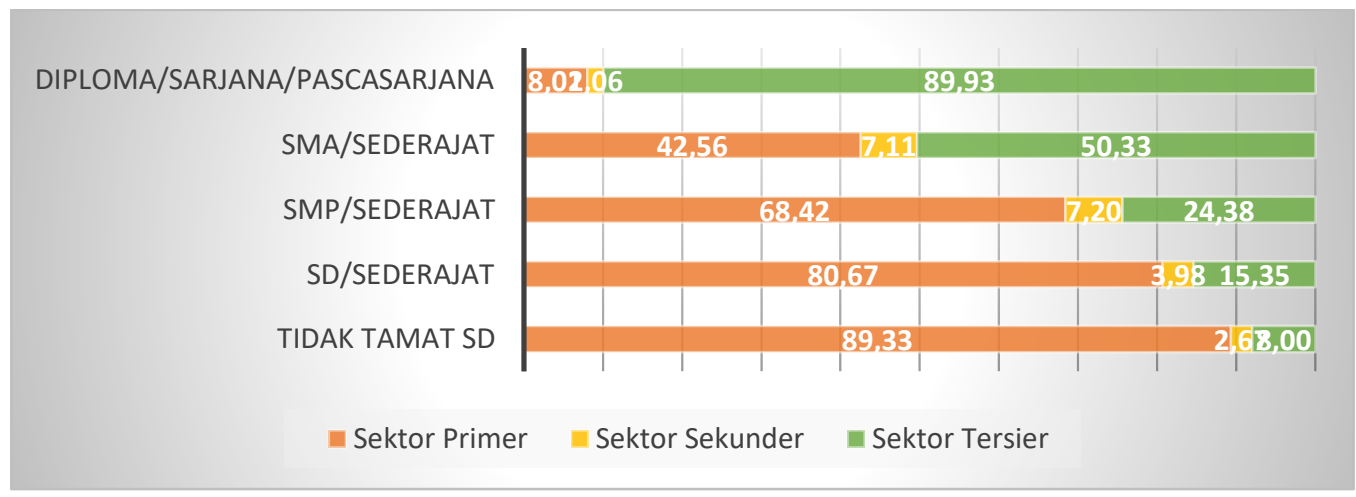

Gambar 10. Persentase ternaga kerja menurut pendidikan terakhir dan sektor usaha Provinsi Bengkulu 2015 
Tenaga kerja SMA ke atas hampir 90\% dari mereka bekerja pada sektor tersier. Beda halnya dengan tingkat pendidikan SMA/Sederajat baik pada sektor tersier dan primer dengan persentase yang tidak berbeda jauh, serta pendidikan SMP ke bawah besar dari $68 \%$ menampu hidupnya pada sektor primer.

Berdasarkan gambaran diatas, dapat diperoleh informasi bahwa sektor tersier didominasi oleh tenaga kerja yang berpendidikan tinggi. Sehingga dapat mendukung fakta bahwa sumbangan terbesar PDRB di Bengkulu didapat dari sektor tersier.

\section{KESIMPULAN}

Berisi simpulan dengan perampatan yang meluas dari pembahasan hasil penelitian yang dituliskan dengan singkat dan jelas, menunjukkan kejelasan sumbangan temuan, pencetusan teori baru dan kemungkinan pengembangan penelitian yang bisa dilakukan kedepannya. Implikasi teoritis dan praktis yang dituliskan dalam paragraf mengalir.

Dari hasil analisis dan pembahasan dapat ditarik kesimpulan bahwa Penduduk bekerja di Provinsi Bengkulu yang masih termasuk kategori miskin masih relatif tinggi. Ketika dilihat dari wilayah, jenis kelamin, dan tingkat pendidikan tenaga kerja di Bengkulu tidak ada perbedaan proporsi pekerja miskin di masing-masing kategori.

Tenaga kerja di Provinsi Bengkulu cenderung bekerja pada sektor Primer lalu disusul sektor tersier. Namun, penyerapan ini tidak sebanding dengan hasil yang seharusnya. PDRB sebagian besar disumbang oleh sektor tersier setelah itu sektor primer. Hal ini terjadi karena jam kerja dari sektor primer relatif rendah dibanding sektor lain. Lalu, sumber daya manusia yang baik cenderung memilih sektor tersier dibanding sekunder dan primer. Sehingga sektor primer tidak dapat menghasilkan output seperti yang diharapkan.

\section{DAFTAR PUSTAKA}

Achmad, Suryana. (2003). Kapita Selekta Evolusi Pemikiran Kebijakan Ketahanan Pangan. Yogyakarta : FE UGM.

Kuncoro, Mudrajad. (2010). Ekonomika Pembangunan: Masalah, Kebijakan, dan Politik (Edisi.5). Jakarta : Penerbit Erlangga.

Akcay, Selcuk. (2011). Causality Relationship Between Total R\&D Investment and Economic Growth: Evidence From United States. The Journal of Faculty of Economics and Administrative Sciences, 16(1), 79-92.

Badan Pusat Statistik (BPS) . 2009. Analisis Kemiskinan, Ketenagakerjaan dan Distribusi Pendapatan. BPS: Jakarta

Badan Pusat Statistik (BPS) . 2010. Konsep Definisi Operasional Baku Statistik Sosial. BPS: Jakarta 
Badan Pusat Statistik (BPS). 2015. Indikator Sosial Ekonomi Provinsi Bengkulu 2015. BPS: Bengkulu.

Bappenas. 2015. Seri Analisis Pembangunan Wilayah Provinsi Bengkulu 2015. Bappenas : Bengkulu.

Boundless. 2016. The Feminization of Poverty.

https://www.boundless.com/sociology/textbooks/boundless-sociology-

textbook/stratification-inequality-and-social-class-in-the-u-s-9/poverty-78/the-

feminization-of-poverty-467-8242/ (Diakses pada tanggal 23 Januari, 2017).

Fahar, F. 2015. Kemiskinan dan Ketenagakerjaan di Kepulauan Riau 2014 : Permasalahan dan Implikasi Kebijakan. https://www.researchgate.net/publication/272052526 (Diakses 25 Desember, 2016)

Osmani, S.R. 2002. Exploring The Employment Nexus: Topics in Employment and Poverty. A Report prepared for the Task Force on the Joint ILO-UNDP Programme on Employment and Poverty.

Puspitasari, Ayu Wulan. 2010. Analisis Faktor-Faktor yang Mempengaruhi Minat Migrasi Sirkuler ke Kabupaten Semarang. (Skripsi : Semarang). 